\title{
DETERMINANTS OF THE REVENUE EFFICIENCY OF INDIAN SCHEDULED COMMERCIAL BANKS
}

\author{
Aparna Bhatia and Megha Mahendru*
}

\begin{abstract}
Research aim: The purpose of this paper is to investigate the internal (bankspecific) and external (macroeconomic and industry-specific) factors thataffect the revenue efficiency of banks.

Design/Methodology/Approach: The paper considers all the Scheduled Commercial Banks operating in India over a period of 22 years from 1991-92 to 2012-13. Due to the non-availability of information for certain variables the sample varies across years. The revenue efficiency of banks is calculated by employing a non-parametric approach, namely, Data Envelopment Analysis (DEA). To determine the factors affecting revenue efficiency, the Panel Data Tobit model, as proposed by James Tobin (1958), is used. It is applied due to the censored nature of the dependent variable, i.e., the efficiency scores, which range from 0 to 1 .

Research finding: The results indicate that the Capital Adequacy Ratio (CAR), Net Non-Performing Assets to Net Advances (NPANA), Operating Expenses to Total Expenses (OETE), Business per Employee (BPE), Return on Assets (ROA), Size (LNTA), and Inflation (INF) reveal a negative relationship with the revenue efficiency scores. Equity to Total Assets (ETA), Total Loans and advances to Total Deposits (TATD), Total Investments to Total Assets (TITA), Total Expenses to Total Income (TETI), Spread to Total Assets (STA), NonInterest Income to Total Income (NIITI), Cash Deposit Ratio (CDR), Time Dummy (TD), Public Dummy (PUBD), and Log of Gross Domestic Product (LNGDP) disclose a positive relationship for the revenue efficiency model.

Theoretical contribution/Originality: This study is among the few that examine factors affecting the revenue efficiency of Indian Commercial Banks as limited research is available in the Indian Banking Literature.

Practitioner/Policy implication: The empirical findings of this article clearly provide assistance to bank managers in understanding the factors that positively or adversely affect the revenue efficiency. It specifically recommends that managers focus on credit risk management and asset liability management.
\end{abstract}

Research limitation/Implication: The present study may be extended by considering other efficiency parameters as dependent variables. Various risks

*Corresponding Author: Megha Mahendru, PhD is an Assistant Professor, Department of Commerce and Business Administration, Khalsa College Amritsar, 143002 Punjab, India. E-mail: Mahendru.megha30@gmail.com

Aparna Bhatia, PhD is an Assistant Professor, University School of Financial Studies, Guru Nanak Dev University Amritsar, 143005 Punjab, India. E-mail: aparnamohindru@yahoo.co.in 
faced by banks and off-balance sheet activities can also be taken into consideration. The impact of other events, such as global financial recession, might also be captured for future research.

Keywords: Revenue Efficiency, Bank Specific Variable, Industry Specific Variable, Data Envelopment Analysis, Panel Tobit Regression Analysis, Indian Scheduled Commercial Banks

Type of manuscript: Research paper

JEL Classification: G2, C24, D61

\section{Introduction}

The efficiency of the banking system is imperative as greater efficiency can enable a bank to earn higher profitability, which provides sufficient safety to absorb huge risks (Egesa, 2010). If banks are fully efficient, it can lead to greater financial stability of the economy and promote economic growth by facilitating financial services to households and firms (Rajan \& Zingales, 1995; Levin, 1997; Cetorelli \& Gambera, 2001; Egesa, 2010; Gulati, 2011; Pančurová \& Lyócsa, 2013). Taking this importance into consideration, the researchers started to measure bank efficiency. Their findings indicate that the literature on measuring bank efficiency has expanded dramatically since the early nineties, and continues to flourish. Extensive studies have investigated the efficiency performance of banks. Efficiency is associated with how a bank produces the largest outputs with the application of given resources, or produces the given outputs by applying a limited quantity of inputs (Mckevitt \& Lawton, 1994).

There are many different factors that affect the efficiency performance of banks, and it is the varying influence of these factors that leads to an increase or decrease in the efficiency. In order to improve the efficiency, banks should identify the factors that affect their efficiency positively or negatively. This would help them in their future planning as well as strengthen their position to face adverse situations like financial crises (Bandaranayake \& Jayasinghe, 2014). Numerous studies have been conducted in several countries to assess the factors that influence bank efficiency, with most of the research papers focusing on analysing the factors that affect the technical efficiency of banks. However, although technical efficiency considers the ability of banks to use their inputs optimally or to produce their outputs efficiently, it does not take into consideration their prices. Merely considering inputsoutputs will not provide much useful information as it will not lead banks to earn financial benefits unless and until their prices are also taken into consideration. Portela and Thanassoulis (2007) also proposed that firms have limited interest in the analysis of technical efficiency as they would only change the quantities of inputs and outputs if this 
would lead them to earn some financial benefit in terms of profit maximisation.

These gaps have encouraged the researchers to enquire into the factors affecting the financial efficiencies of banks, i.e., cost efficiency and revenue efficiency. Cost efficiency reveals whether room exists for a bank to reduce its cost if it operates efficiently, while revenue efficiency indicates whether or not the bank is producing maximum outputs using the available inputs for the purpose of increasing revenue. In order to improve efficiency, most banks focus on cost minimisation, but, in this era of profit maximisation, it is not feasible for banks to merely reduce cost; they must also focus on the revenue side. Moreover, in the real world, bank managers are given output targets to achieve efficiently by optimizing the use of inputs, thus making the revenue efficiency more important from the point of view of banks (Sahoo et al., 2007). Furthermore, the literature on banking that merely focuses on cost efficiency has been criticised for ignoring the revenue efficiency of the banks because high cost incurring banks, i.e., a cost inefficient bank, might be able to generate higher profits than a cost-efficient bank (Berger and Mester, 1997 and Berger and Humphrey, 1997). This is because banks offer products and services through technology, which increases their costs and makes them inefficient in terms of cost, whereas generating higher revenue results in making higher profits. This discloses that the revenue side of banks is noteworthy in order to recognise the precise performance of the banks. Additionally, the factors affecting the evaluation of revenue efficiency can direct an inefficient bank to recognise the areas of inefficiency so that it can formulate suitable policies and strategies to improve its relative position in the market.

The paper is divided into six sections. Section 1 introduces the background concerning bank efficiency. Section 2 reviews the associated studies to ascertain the research gap in the available literature and frames the hypotheses. Section 3 discusses the database and Section 4 explains the model specifications. Section 5 focuses on the results and discussion. Finally, Section 6 concludes the study.

\section{Literature Review and Hypothesis Development}

After reviewing the literature on the factors affecting the efficiency of banks, only two studies were found; namely, Sufian et al. (2012), and Sufian and Kamarudin (2015), that determine the factors influencing the revenue efficiency of banks. Sufian et al. (2012) examined the relationship of the Revenue Efficiency of Malaysian Islamic Banks with other 
explanatory bank specific and economy specific variables by employing Panel Regression Analysis. The sample comprised 11 domestic and 6 Foreign Islamic banks for the period from 2006 to 2010. The results of the regression showed that capitalisation, market power, and liquidity had a significant influence on the revenue efficiency of Malaysian domestic Islamic banks. Further, the study did not find a significant impact of macroeconomic conditions on the revenue efficiency levels of the domestic Islamic banks. Sufian and Kamarudin (2015) identified the factors that affected the Revenue Efficiency of 17 Islamic Banks operating in Malaysia, Indonesia, and Brunei from 2006 to 2011. The study applied Panel Regression Analysis based on the Ordinary Least Squares and Generalised Least Squares methods. The study reported that bank size, asset quality, capitalisation, liquidity, and management quality had a significant impact on the Revenue Efficiency of the Islamic Banks operating in Malaysia, Indonesia, and Brunei. Inflation showed a negative and significant coefficient indicating an adverse relationship with Revenue Efficiency.

With reference to India, only the two studies of Ram Mohan and Ray (2004), and Bhatia and Mahendru (2015) evaluated the revenue efficiency of Indian Scheduled Commercial Banks. However, these studies only provided limited insights as they only calculated the revenue efficiency scores of banks, i.e., one stage analysis only. Moreover, neither study determined which factors affect, either positively or negatively, the revenue efficiency. An evident research gap is seen as none of the studies available evaluated the factors affecting the Revenue Efficiency of Indian Banks. The current article comprises a two stage analyses, i.e., after calculating the revenue efficiency scores for banks, these scores are used to analyse the factors that affect the revenue efficiency scores of banks. The current paper is an extension of the previous papers that were very elementary in nature and simply focussed on the calculation of the revenue efficiency scores alone. The present paper involves determination of the variables/attributes affecting the revenue efficiency using the CAMEL framework. This type of objective has, to the authors knowledge, not been addressed before with reference to the Indian context. Thus, in the Indian context, there is an overwhelming need to determine the factors affecting the revenue efficiency of the banking sector. Thus, the main objective of the paper is to evaluate the factors that have a significant effect on revenue efficiency.

Several bank, industry, and economy specific factors may influence a particular bank's revenue efficiency. For building the hypotheses, the theoretical as well as the empirical relationship of various variables with 
revenue efficiency are considered. These variables are explained along with their hypotheses; as follows.

\subsection{Bank Specific Variables}

Numerous bank specific variables like bank's capital, leverage, cash availability, interest income, non-interest income, operating expenses, non-operating expenses, size, ownership, and market share may affect the efficiency performance of banks. Researchers around the globe have selected these variables randomly for their research. The present study puts these independent variables into a well-defined structure as per the CAMEL framework and controls the effect of size and time. The CAMEL Framework was developed in the US in 1979 and its supervisory regulators include the Federal Reserve, the Office of the Comptroller of the Currency, National Credit Union Administration, and the Federal Deposit Insurance Corporation. The CAMEL framework is an assessment criterion, or a quantitative technique used to classify a bank's overall condition. It evaluates the performance of banks through some vital parameters as C-Capital Adequacy, A- Asset Quality, M- Management Soundness, E- Earnings Quality, and L- Liquidity Management. Thus, this framework includes financial as well as managerial indicators of a bank's performance and is very organised and exhaustive. These bank specific variables parameters are explained as follows.

\subsubsection{Bank Specific Variables as per the CAMEL Framework}

\subsubsection{Capital Adequacy}

A bank's capital is the amount of the bank's own funds that act as a safety stock in case of unfavourable conditions (Athanasoglou et al., 2006). In the present article, two ratios; namely, the Capital Adequacy Ratio (CAR) and Equity to Total Assets (ETA) ratio are used to measure the capital strength of the banks.

\subsection{Capital Adequacy Ratio (CAR)}

The Capital Adequacy Ratio (CAR) depicts the minimum capital requirement that banks have to hold with themselves. A high CAR depicts that well-capitalised banks require less borrowing, which leads to a reduction in their cost of borrowing and makes them efficient (Gupta et al., 2008 and Ghosh, 2009). In addition, it can absorb a greater level of unexpected losses. In the present study the following hypothesis has been framed: 
$H_{1}$ : There is a positive relationship between the Capital Adequacy Ratio and Revenue Efficiency.

\subsection{Equity to Total Assets (ETA)}

Equity to Total Assets is one of the measures used to evaluate the strength of the capital of a bank (Pasiouras \& Kosmidou, 2007). A high proportion of equity capital would decrease the cost of capital of a bank, thus enhancing the profitability and efficiency of the bank (Molyneux, 1993). A ratio of low equity to the total assets of a bank may influence the confidence and the safety of the customer for the respective bank. The following hypothesis has been framed and tested in this study:

$\mathrm{H}_{2}$ : There is a positive relationship between the Equity to Total Assets ratio and Revenue Efficiency.

\subsubsection{Asset Quality}

Loans and Advances and Investments are the primary assets of banks that generate a major share of a bank's income. So, loan quality has a direct bearing on the efficiency of banks. In order to measure the asset quality of a bank, three ratios are considered, namely, Net NonPerforming Assets (NPA) to Net Advances, Total Investments to Total Assets (TITA), and Total Loans and advances to Total Deposits (TATD).

\subsection{Net Non-Performing Assets to Net Advances (NPANA)}

Non-Performing Assets (NPAs) represent the bad loans on which the borrowers fail to satisfy their repayment commitment. The more a bank is exposed to these types of bad loans, the lower the efficiency of the bank (Joseph and Prakash, 2014). A high Net Non-Performing Assets (NPAs) to Net Advances ratio reflects a rise in the bad quality of loans in relation to total loans and advances; whereas a lower ratio indicates the better performance of a bank. The foregoing arguments help to develop the following hypothesis:

$H_{3}$ : There is a negative relationship between Non-Performing Assets (NPA) to Net Advances and Revenue Efficiency.

\subsection{Total Investments to Total Assets (TITA)}

A bank's investments include investment in government securities, other approved securities, shares, debentures, bonds, and other non-approved investments. These investments help banks to earn good returns with low risk and to protect themselves from huge NPAs; however, investments are often considered as evidence of lazy banking as the 
primary business of the banks is to lend (Ketkar \& Ketkar, 2008). A higher level of investments may also indicate poor credit off-take or conservative lending (Chisti, 2012). The following hypothesis is framed and tested:

$H_{4}$ : There is a positive/negative relationship between Total Investments to Total Assets and Revenue Efficiency.

\subsection{Total Loans and advances to Total Deposits (TATD)}

The Loans and advances to the Deposit ratio reflects the ability of a bank to use its available resources in the most advantageous manner by converting the available deposits into high earning loans and advances. A higher ratio depicts that higher loans and advances are formed from the deposits by banks. Further, it indicates that the banks generate more income from their loans and advances. Thus, from the above discussion, the following hypothesis is developed:

$H_{5}$ : There is a positive/negative relationship between Total Loans and advances to Total Deposits and Revenue Efficiency.

\subsubsection{Management Soundness}

Management Soundness shows the capability of management to deploy its resources (Purohit and Mazumdar, 2003). This can be judged from the proficiency of managers to minimise their expenses and obtain the best returns from these expenses. Thus, management soundness is analysed by three ratios, namely: Total Expenses to Total Income (TETI), Operating Expenses to Total Expenses (OETE), and Business per employee (BPE).

\subsection{Total Expenses to Total Income (TETI)}

This ratio gives the information about the competence of the management regarding the expenses incurred in relation to the income generated by the bank. A high ratio implies less efficient management suggesting that the banks are not able to maintain their expenses at the minimum (Pasiouras \& Kosimidou, 2007), while a lower ratio indicates the greater profitability of the banks (Makkar \& Singh, 2012). The current study also draws the hypothesis that:

$H_{6}$ : There is a negative relationship between Total Expenses to Total Income and Revenue Efficiency. 


\subsection{Operating Expenses to Total Expenses (OETE)}

Poor management of operating expenses may lead to the lower profitability and efficiency of banks (Kosmidou, 2008). In other words, a decrease in expenses will improve the efficiency of the banks. Hence, the following hypothesis is tested:

$H_{7}$ : There is a negative relationship between Operating Expenses to Total Expenses and Revenue Efficiency.

\subsection{Business per employee (BPE)}

Employees play a crucial role in providing services to the customers of the banks. Banks do not simply make a product to offer to their customers, rather they offer them services through their employees. So, to assess management soundness, it becomes necessary to evaluate the business generated per employee. This ratio shows the productivity of the workforce of a bank. The higher the ratio, the higher the efficiency of a bank in providing services to the customers. Bala and Kumar (2011) found a positive and significant impact of BPE on the efficiency of banks. However, although Gupta et al. (2008) also reported a positive impact the relation was insignificant. Furthermore, Kumar and Gulati (2009), and Gulati (2011a) found a negative relation between the two but it was also insignificant. In the current study, the following hypothesis is framed:

$H_{8}$ : There is a positive relationship between Business per Employee and Revenue Efficiency.

\subsubsection{Earnings Quality}

Earnings Quality refers to the profits earned by a bank and is calculated by deducting the expenses from the income generated. In order to measure the earnings quality of a bank, three ratios are used, namely, Return on Assets (ROA), Spread to Total Assets (STA), and Non-Interest Income to Total Income (NIITI).

\subsection{Return on Assets (ROA)}

Return on Assets indicates a bank's effectiveness in utilising its assets for generating profits. A higher ROA indicates the superior quality of assets in generating income, which leads to the higher efficiency of the bank (Ataullah \& Le, 2006). For the current study, the following hypothesis is framed:

H9: There is a positive relationship between Return on Assets and Revenue Efficiency. 


\subsection{Spread to Total assets (STA)}

Spread is the difference between the interest received and the interest paid. Spread shows the competence of a bank in managing and matching its interest expenditure with the interest income effectively. In other words, a high spread for a bank shows the ability of a bank to earn high interest on advances and to pay low interest on deposits (Chisti, 2012). It actually ensures the effective Asset Liability Management (ALM) in a bank. Thus, the following hypothesis is framed:

$H_{10}$ : There is a positive relationship between Spread to Total Assets and Revenue Efficiency.

\subsection{Non-Interest Income to Total Income (NIITI)}

The ratio of Non-Interest Income to Total Income depicts how much the portion of total income includes non-interest income. A higher share of non-interest income shows that the bank is less dependent on the interest income. Moreover, this diversification helps banks earn additional profits and indicates managerial efficiency (Sufian, 2009). In the present study, the following hypothesis is framed:

$H_{11}$ : There is a positive relationship between Non-Interest Income to Total Income to Total Assets and Revenue Efficiency.

\subsubsection{Liquidity Management}

Liquidity refers to the ability of a bank to pay back the money demanded by the depositors. Banks will only be able to meet their money demand if they maintain sufficient funds with themselves. This depicts the capability of a bank to achieve a balance between the sources and the use of funds (Alshatti, 2015). Liquidity Management is analysed by using two ratios, namely, Cash Deposits Ratio (CDR) and Liquid Assets to Total Assets (LATA).

\subsection{Cash Deposit Ratio (CDR)}

Absolute Liquidity in the case of a bank refers to the cash available with the bank. The Cash Deposit Ratio depicts the amount of deposits retained by the bank in the form of cash. The optimal amount of cash maintained with banks will help them maintain a balance between profitability and liquidity. Ignoring liquidity may create financial problems and result in a mess with the subsequent withdrawal of deposits (Alshatti, 2015). On the other hand, a higher proportion of bank deposits in the form of cash and cash equivalents indicates that the bank has not lent its money or 
invested its money to generate income. Thus, the following hypothesis is framed:

$H_{12}$ : There is a positive/negative relationship between the Cash Deposit Ratio to Total Assets and Revenue Efficiency.

\subsection{Liquid Assets to Total Assets (LATA)}

The ratio of Liquid Assets to Total Assets indicates the overall liquidity position of a bank in relation to total assets. A high Liquid Asset to Total Asset ratio indicates incompetence on the part of bank management in organizing their resources in higher interest yielding assets (Elsiefy, 2013). Banks with more liquid assets depict poor cash management, thereby suggesting that banks have not lent their money as loans and advances and have failed to generate a major proportion of the bank's income in the form of interest. In the present study, the following hypothesis is framed and tested:

$H_{13}$ : There is a positive/negative relationship between Liquid Assets to Total Assets and Revenue Efficiency.

\subsubsection{Control Variables}

\subsubsection{Size (LNTA)}

The size of a bank is the most important variable affecting the efficiency of banks. The size effect is captured by taking the natural Logarithm of Total Assets. Large banks enjoy higher economies of scale than small banks (Staikouras \& Wood, 2004; Kosmidou et al., 2005; Elsiefy, 2013). Thus, large sized banks are likely to be more efficient as the economies generated on account of their size help them to reduce the per unit cost of gathering and processing information (Boyd \& Runkle, 1993; Pasiouras et al., 2007). Larger banks are relatively better than smaller banks as they can easily expand their business and can compete with their counterparts (Sufian, 2009). Thus, the following hypothesis is tested in the study:

$H_{14}$ : There is a positive/negative relationship between Size and Revenue Efficiency.

\subsubsection{Time Dummy (TD)}

The Time Dummy is used to incorporate the effect of the introduction of reforms on the efficiency of banks. A dummy value of 1 is given for the Reformatory era and 0 for the Post Reformatory Era. It may impact the efficiency of banks positively or negatively. Therefore, the following hypothesis is tested in the study: 
$H_{15}$ : There is a positive/negative relationship between Time Dummy and Revenue Efficiency.

\subsubsection{Industry Specific Variables}

Several industry specific variables also influence the efficiency of banks. In the present study, two industry specific variables are considered, namely, Ownership and Market Share in terms of Total Assets.

\subsubsection{Ownership Dummy}

The Indian Banking System has a diverse ownership that is split into Public Sector Banks, Private Sector Banks, and Foreign Sector Banks. To capture the impact of ownership, two dummies are considered as independent variables; one dummy for Public Sector Banks (PUBD) with a value of 1 assigned to these and 0 for all other banks. Similarly, another dummy of Private Sector Banks (PVTD) is created, while Foreign Sector Banks are considered as the reference sector. Since there is no clear empirical evidence with respect to the efficiency of banks on the basis of ownership, the following hypotheses are framed and tested:

$H_{16}$ : There is a positive/negative relationship between Public Dummy and Revenue Efficiency.

$H_{17}$ : There is a positive/negative relationship between Private Dummy and Revenue Efficiency.

\subsubsection{Market Share in terms of Total Assets (MSTA)}

The Market Share in terms of Total Assets depicts the share of assets held by a bank in relation to the total assets of the banking sector. In other words, it is calculated by dividing a particular bank's assets by the banking sector's total assets. A bank having a high market share is able to compete effectively in the market (Garza-García, 2012). In the current study, the following hypothesis is tested:

$H_{18}$ : There is a positive relationship between Market Share in terms of Total Assets and Revenue Efficiency.

\subsection{Economy Specific variables}

The economy specific variables are beyond the control of banks and their impact appears at the macro level. Favourable economic conditions encourage banks to lend more loans and advances and earn higher returns while unfavourable conditions restrict their lending activities 
(Sufian, 2009). Two important macro variables, namely, Inflation and Gross Domestic Product, are used in the present study.

\subsubsection{Inflation (INF)}

Inflation directly affects the prices of goods and services. It also affects the interest rate of banks, thus directly affecting their efficiency. The effect of inflation on bank's performance depends on whether the inflation is anticipated or unanticipated (Perry, 1992). Anticipated inflation implies that banks anticipate the inflation rate and adjust their interest rates timely and increase their revenues more as per the increase in their cost (Athanasoglou et al., 2005). Thus, the following hypothesis is framed and tested in the present study:

$H_{19}$ : There is a negative relationship between Inflation and Revenue Efficiency.

\subsubsection{Gross Domestic Product (GDP)}

GDP is used to indicate the macroeconomic environment of the country. It affects a bank's performance in accordance with the economic conditions existing within an economy (Alexiou \& Sofoklis, 2009). GDP has a direct effect on the supply of deposits to the banks and demand for loans from the banks (Sufian, 2009). Sufian and Noor (2009) mentioned that a high Gross Domestic Product indicates that favourable economic conditions prevail in the economy. This enables banks to earn better returns from their loans and advances (Pasiouras \& Kosmidou, 2007). On the other hand, a slowdown in Gross Domestic Product reduces the credit quality and increases the default rate, thereby reducing the bank's efficiency (Sufian \& Habibullah, 2010). GDP is used by taking the natural Logarithm of the Gross Domestic Product (LNGDP). The following hypothesis is tested in the present study:

$H_{20}$ : There is a positive relationship between Gross Domestic Product and Revenue Efficiency.

\section{Methodology}

\subsection{Sample Selection}

The article follows a two-stage analysis; in the first stage, the revenue efficiency for each bank is calculated over the total time period of 22 years from 1991-92 to 2012-13. In the second stage of analysis, the Panel Data Tobit Regression model is used with the revenue efficiency scores obtained in the first stage as the dependent variables. 
The time period of 22 years represents different vital phases through which the Indian Economy has travelled. The initial years (1991-92 to 1999-2000) witnessed prosperity for the Indian Banks as they were capitalising the benefits of various reforms introduced in the banking sector in the 1990s - the Narasimham Committee Report was introduced in 1991, second, the Basel Norms in 1998, followed by Know Your Customer (KYC), and Anti-money Laundering (AML), etc. The middle years (2000-01 to 2006-07) were gloomy for the banks as the US financial bubble hit the global financial sector adversely and Indian Banks also faced the heat. The later years (2007-08 to 2012-13) signify the time period when the economy was trying to recover from the global financial crisis and awaiting prosperity.

The sample of the study includes all the Scheduled Commercial Banks operating in India during 1991-92 to 2012-13. The number of banks varies across time due to missing observations and the non-availability of data for some banks for certain years. Accordingly, the effective sample of the banks varies from a minimum of 72 to a maximum of 84 from year to year. The source of financial data is the official website of the Reserve Bank of India (RBI), which is considered to be the most comprehensive database for research in banking.

\subsection{Data Envelopment Analysis (DEA)}

Data Envelopment Analysis (DEA) is a linear programming based technique employed for assessing the relative performance of a set of firms against the best-observed performance. DEA identifies the efficiencies of all firms in relation to the best practice firm in the sample. A firm in DEA is known as a Decision-Making Unit (DMU). The major endeavour of the DEA is to construct the frontier from the most efficient decision-making unit, then, to measure how far the inefficient DMUs are from the frontiers. Moreover, it also helps DMUs to identify the areas for improvement by confirming whether the input has been excessively used or the output has been produced less. The present paper uses DEA to measure the Revenue Efficiency of Banks. Revenue Efficiency is an output-oriented model, as it maximises outputs at a given level of input quantities given the output prices. The Mathematical programming equations used to calculate the Revenue Efficiency of banks is as follows:

$$
\operatorname{Max}=\sum_{\mathrm{r}=1}^{\mathrm{s}} \mathrm{q}_{\mathrm{r}}^{\mathrm{o}} \mathrm{y}_{\mathrm{ro}}
$$




$$
\begin{array}{cc}
\text { Subjectto } \sum_{j=1}^{n} \lambda_{j} x_{i j} \leq x_{i o} & i=1,2, \ldots, m \\
\sum_{i=1}^{n} \lambda_{j} y_{r j} \geq y_{\text {ro }} & r=1,2, \ldots, s \\
\lambda_{j}, y_{r o} \geq 0 & \\
\sum_{i=1}^{n} \lambda_{j}=1
\end{array}
$$

where

$\mathrm{n}=$ number of DMUs

$\mathrm{j}=\mathrm{n}^{\text {th }} \mathrm{DMU}$

$\mathrm{s}=$ output observation

$\mathrm{m}=$ input observation

$\mathrm{r}=\mathrm{s}^{\text {th }}$ output

$\mathrm{i}=\mathrm{m}^{\text {th }}$ input

$\mathrm{q}_{\mathrm{r}}^{\mathrm{o}}=$ unit price of the output $\mathrm{r}$ of $\mathrm{DMU}_{\mathrm{O}}$

$\mathrm{p}_{\mathrm{i}}^{\mathrm{o}}=$ unit price of the input $\mathrm{i}$ of $\mathrm{DMU}_{\mathrm{O}}$

$\widetilde{\mathrm{y}}_{\mathrm{ro}}=\mathrm{r}^{\text {th }}$ output that maximise revenue for $\mathrm{DMU}$

$\tilde{\mathrm{x}}_{\mathrm{io}}=\mathrm{i}^{\text {th }}$ input that minimise cost for DMUO

$\mathrm{y}_{\mathrm{ro}}=\mathrm{r}^{\text {th }}$ output for $\mathrm{DMU}_{\mathrm{O}}$

$\mathrm{x}_{\mathrm{io}}=\mathrm{i}^{\text {th }}$ input for $\mathrm{DMU}_{\mathrm{O}}$

For calculating the efficiency scores, DEA requires the selection of inputs and outputs. The banking literature suggested that two approaches - Production Approach (operating approach) and Intermediate Approach - are constantly used for the selection of inputs and outputs. The Production Approach is the contribution of Benston (1965), and Bell and Murphy (1968) and presumes that banks serve as the producer of services for account holders. This approach considers that banks use purchased inputs, i.e., operating cost and interest expenses to produce deposits and loans and advances (Avkiran, 2000). The Intermediate Approach supposes that banks act as financial intermediaries and that their main role is to obtain funds from the savers and further lend these funds to the borrowers for making profit. To evaluate the efficiency of the banks, the Intermediation Approach is generally preferred as banks are considered to work as financial 
intermediaries. The Intermediate Approach assumes that banks act as financial intermediaries whose main role is to obtain funds from the savers and to lend these funds further to the borrowers for making profit. Sticking with the Intermediation Approach, this paper uses four inputs and three outputs. Deposits, borrowings, fixed assets, and the number of employees are the inputs whereas investments, loans and advances, and non-interest income are the various outputs used in the study. In addition, the Prices of outputs were calculated, i.e., Price of investments (Income (interest and dividend received) from Investments/ Investments), Prices of Loan and Advances (Interest received from loans and advances/Loans and Advances), and Prices of Non-interest Income (Assumes the Price of non-interest income as unity throughout the years for all banks).

\subsection{Panel Data Tobit Regression}

The Panel Data Tobit model was proposed by James Tobin (1958) to describe the relationship between a censored dependent variable and the independent variables. The simple application of the OLS estimation procedure in the censored dependent variable may produce biased estimates if there is a significant position of the observation equal to 1 (Saxonhouse, 1976; Resende, 2000; Kumar \& Gulati, 2008; Gulati, 2011). Thus, the Panel Data Tobit model is applied due to the censored nature of the dependent variable, as, in the current situation, the efficiency scores are censored in nature ranging from 0 to 1 . The Tobit model is applied due to the censored nature of the dependent variable as well as the extreme values of the independent variables, which deviate from a normal distribution and are highly skewed in nature. The present study is based on 1790 bank year observations for a period of 22 years, thus suggesting that the Panel Tobit Regression Model is to be used. Thus, to estimate the factors affecting the Revenue Efficiency score, the Randomeffects Panel Tobit model is used. The Random-effects Panel Tobit model for $\mathrm{i}^{\text {th }}$ banks can be specified as:

$$
\begin{gathered}
y_{i t}^{*}=\beta^{\prime} x_{i t}+u_{i t} i=1,2,3 \ldots . N, t=1,2,3, \ldots \ldots ., T \\
u_{i t}=v_{i}+\varepsilon_{i t}
\end{gathered}
$$

Where, $x_{i t}$ is a vector of the explanatory variables and the common error term $u_{i t}$ could be freely correlated over time. The error term $u_{i t}$ can be split into a time-invariant individual Random-Effect (RE) $v_{i}$ and a time-varying idiosyncratic random error $\varepsilon_{i t}$. Thus, the Random-effects Panel Tobit model can be considered in the following form: 


$$
y_{i t}^{*}=\beta^{\prime} x_{i t}+v_{i}+\varepsilon_{i t}
$$

The observed variable for left-censored and right-censored observations is:

$$
\begin{aligned}
& y_{\text {it }}=\left\{\begin{array}{l}
y_{\text {it }}^{*} \text { If } y_{\text {it }}^{*}>0 \\
0 \text { otherwise }
\end{array}\right. \\
& y_{\text {it }}=\left\{\begin{array}{l}
y_{\text {it }}^{*} \text { If } y_{\text {it }}^{*}<1 \\
0 \text { otherwise }
\end{array}\right.
\end{aligned}
$$

In this study, the second stage of analysis is done by employing the Random-Effect Panel Tobit Regression Model to determine the effects of the bank specific, industry specific, and economy specific factors on the revenue banks' efficiency parameter. Before applying Panel Tobit regression, all assumptions required have been checked and all were found to be satisfactory.

\section{Empirical Analysis}

Table. 1 Revenue Efficiency Scores of Indian Scheduled Commercial Banks

\begin{tabular}{cccc}
\hline Year & Revenue Efficiency & Year & Revenue Efficiency \\
\hline $1991-92$ & .792 & $2002-03$ & .614 \\
$1992-93$ & .757 & $2003-04$ & .662 \\
$1993-94$ & .789 & $2004-05$ & .658 \\
$1994-95$ & .799 & $2005-06$ & .524 \\
$1995-96$ & .781 & $2006-07$ & .797 \\
$1996-97$ & .785 & $2007-08$ & .772 \\
$1997-98$ & .711 & $2008-09$ & .722 \\
$1998-99$ & .731 & $2009-10$ & .648 \\
$1999-2000$ & .709 & $2010-11$ & .679 \\
$2000-01$ & .690 & $2011-12$ & .612 \\
$2001-02$ & .642 & $2012-13$ & .572 \\
\hline
\end{tabular}

The Revenue Efficiency measures the relative performance of a bank against the best practice bank. In this section, the Revenue Efficiency (RE) for each bank is calculated for each year during 1991-92 to 2012-13, and the scores are taken to evaluate the factors that have a significant effect on the revenue efficiency of Indian Scheduled Commercial Banks. Table 1 shows the average revenue efficiency Scores.

These revenue scores based on the year-wise observation of 1790 banks for a period of 22 years from 1991-92 to 2012-13 were used to apply Panel Tobit Regression. In Table 2, when Panel Tobit Regression is run with Revenue Efficiency scores as the dependent variable, the Capital Adequacy Ratio (CAR) reveals a negative relationship with Revenue Efficiency and is statistically significant at the 1 per cent level of 
significance. Equity to Total Assets (ETA) reveals a positive relationship and is statistically significant at the 1 per cent level of significance with Revenue Efficiency. Net Non-Performing Assets to Net Advances (NPANA) has a negative relationship with Revenue Efficiency and is statistically significant at the 1 per cent level of significance.

Table. 2 Results of Panel Tobit Regression

\begin{tabular}{|c|c|c|c|c|c|}
\hline & \multicolumn{2}{|l|}{ Independent Variables } & \multicolumn{3}{|c|}{ Dependent Variable Revenue Efficiency } \\
\hline & Framework & Symbol & Coeff. & Std. Err. & $\mathrm{P}>\mathrm{z}$ \\
\hline Capital & Capital Adequacy Ratio & CAR & $-.0016^{*}$ & .0004 & .000 \\
\hline Adequacy & $\begin{array}{l}\text { Equity Capital to Total } \\
\text { Assets }\end{array}$ & ETA & $.0053^{*}$ & .0009 & .000 \\
\hline \multirow[t]{3}{*}{$\begin{array}{l}\text { Asset } \\
\text { Quality }\end{array}$} & $\begin{array}{l}\text { Net NPAs to Net } \\
\text { Advances }\end{array}$ & NPANA & $-.0037^{*}$ & .0008 & .000 \\
\hline & $\begin{array}{l}\text { Investment to Total } \\
\text { Assets }\end{array}$ & TITA & $.0098^{*}$ & .0005 & .000 \\
\hline & $\begin{array}{l}\text { Total Loans and } \\
\text { advances to Total } \\
\text { Deposits }\end{array}$ & TATD & .0000 & .0000 & .475 \\
\hline \multirow[t]{3}{*}{$\begin{array}{l}\text { Management } \\
\text { Soundness }\end{array}$} & $\begin{array}{l}\text { Total Expenses To Total } \\
\text { Income }\end{array}$ & TETI & $.0009^{* *}$ & .0004 & .034 \\
\hline & $\begin{array}{l}\text { Operating Expenses/ } \\
\text { Total Expenses }\end{array}$ & OETE & $-.0029^{*}$ & .0006 & .000 \\
\hline & Business Per Employee & $\mathrm{BPE}$ & $-.0002^{* *}$ & .0001 & .016 \\
\hline Earning & Return on Assets & ROA & $-.0057^{* *}$ & .0027 & .04 \\
\hline \multirow[t]{2}{*}{ Quality } & Spread To Total Assets & STA & $.0138^{* *}$ & .0056 & .014 \\
\hline & $\begin{array}{l}\text { Non-Interest Income To } \\
\text { Total Income }\end{array}$ & NIITI & $.0014^{\star *}$ & .0007 & .042 \\
\hline Liquidity & Cash Deposit Ratio & CDR & $.0060^{*}$ & .0009 & .000 \\
\hline Management & $\begin{array}{l}\text { Liquid Assets To Total } \\
\text { Assets }\end{array}$ & LATA & .0001 & .0007 & .879 \\
\hline Bank Size & Log of Total Assets & LNTA & $-.0233^{*}$ & .0078 & .003 \\
\hline Time & Time Dummy 1 & TD & $.03427^{* * *}$ & .0175 & .051 \\
\hline Industry & Public Dummy & PUBD & $.1195^{*}$ & .0336 & .000 \\
\hline \multirow[t]{2}{*}{ Specific } & Private Dummy & PVTD & $.0502^{* * *}$ & .0261 & .055 \\
\hline & $\begin{array}{l}\text { Market Share in terms of } \\
\text { total assets }\end{array}$ & MSTA & .0000 & .0043 & .992 \\
\hline Economy & Inflation (WPI) & INF & $-.0025^{*}$ & .0009 & .008 \\
\hline Specific & Log of GDP & LNGDP & $.2746^{*}$ & .0841 & .001 \\
\hline Constant & & Const & $-2.0956^{*}$ & .7670 & .006 \\
\hline \multirow{2}{*}{\multicolumn{3}{|c|}{$\begin{array}{c}\text { Log Likelihood } \\
\text { Wald chi2(22) }\end{array}$}} & 236.678 & & \\
\hline & & & $509.51^{*}$ & & \\
\hline
\end{tabular}

It is observed that Total Investments to Total Assets (TITA) exhibits a positive relationship with Revenue Efficiency, and is significant at the 1 per cent level of significance. Total Loans and advances to Total Deposits (TATD) reveals a positive relationship with Revenue Efficiency but it is statistically insignificant. Total Expense to Total Income (TETI) was expected to have a negative impact but it turned out to be reverse in the case of Revenue Efficiency, which is significant at the 5 per cent level of 
significance. Operating Expenses to Total Expenses (OETE) has a negative relationship with Revenue Efficiency and is statistically significant at the 1 per cent level of significance. Business per Employee (BPE) has a negative impact on the Revenue Efficiency and is statistically significant at the 5 per cent level of significance.

Return on Assets (ROA) reveals a negative relationship with Revenue Efficiency and is statistically significant at the 5 per cent level of significance. Spread to Total Assets (STA) has a positive impact on the Revenue Efficiency, which is statistically significant at the 5 per cent level of significance. It is observed that Non-Interest Income to Total Income (NIITI) exhibits a positive relationship with Revenue Efficiency and is statistically significant at the 5 per cent level of significance. Cash Deposit Ratio (CDR) exhibits a positive and statistically significant relationship with Revenue Efficiency, and is significant at the 1 per cent level of significance.

However, LATA has a positive, but insignificant impact on Revenue Efficiency. Size (LNTA) reveals a negative relationship with the Revenue Efficiency scores, which is statistically significant at the 1 per cent level of significance. Time Dummy (TD) reveals a positive relationship with Revenue Efficiency and is statistically significant at the 10 per cent level of significance. Public Dummy (PUBD) reveals a positive relationship with Revenue Efficiency and is statistically significant at the 1 per cent level of significance.

Private Dummy (PVTD) also portrays a positive relation with Revenue Efficiency and is significant at the 10 per cent level of significance. Market Share in terms of Total Assets has a positive impact on the Revenue Efficiency, but the coefficient is statistically insignificant. Inflation (INF) reveals a negative relationship and is statistically significant at the 1 per cent level of significance for Revenue Efficiency. Log of Gross Domestic Product (LNGDP) has a positive and statistically significant relationship with Revenue Efficiency and is significant at the 1 per cent level of significance.

The Panel Tobit Regression Analysis has been run to test the hypotheses. All variables, i.e., bank specific, industry specific, and economy specific for which the hypotheses have been tested are stated as follows

\subsection{Capital Adequacy Ratio (CAR)}

Contrary to our hypothesis $\left(\mathrm{H}_{1}\right)$, CAR reveals a negative relationship with the revenue efficiency parameters in our results. This negative relation implies that banks with a higher Capital Adequacy Ratio tend to 
have lower efficiency scores. CAR provides a cushion to banks against the unexpected losses. Indian Scheduled Commercial Banks are averse to risk in nature. Due to this, on the one hand, they invest in safer and low earning portfolios (Bhattacharyya et al., 1997; Kumar \& Gulati, 2009), but, on the other, they tend to maintain a high CAR of much higher than the prescribed norm of 9 per cent. As a result, there is disequilibrium between the inputs and outputs affecting efficiency negatively, thus leading to rejection of the hypothesis. The findings are consistent with the earlier findings of Bhattacharyya et al. (1997), Kumar and Gulati (2009), and Gulati (2011) who found that CAR had a negative relation with the efficiency scores.

\subsection{Equity to Total Assets (ETA)}

Equity to Total Assets (ETA) reveals a positive relationship with Revenue Efficiency suggesting that banks with higher equity tend to have higher efficiency scores. This positive coefficient of equity to total assets portrays that banks with more capital are more efficient as with their strong capital base they are able to face unexpected losses, specifically, those arising from Non-Performing Assets (NPAs). They can expand their business to earn better profits. Moreover, highly capitalised banks are better able to face economic difficulties than thinly capitalised ones (Dietrich \& Wanzenried, 2009). Our results for $\mathrm{H}_{2}$ are supported by Grigorian and Manole (2002), Pasiouras et al. (2007), Semih Yildirim and Philippatos (2007), Ioannis et al. (2008), Sufian and Noor (2009), Brack and Jimborean (2010), Sufian and Habibullah (2010), Sufian et al. (2012), Sanchez et al. (2013), Pančurová and Lyócsa (2013), and Raphael (2013) who reported the positive association of ETA with the efficiency of banks, thus providing support that higher capital helps banks be less dependent on external funding resulting in higher efficiency.

\subsection{Net Non-Performing Assets to Net Advances (NPANA)}

For $\mathrm{H}_{3}$, Net Non-Performing assets to Net Advances (NPANA) reveals a negative relationship with Revenue Efficiency, which depicts that a high level of Non-Performing Assets adversely affects the efficiency of banks. Obviously, the non-repayment of principal and interest would bring inefficiency on the Revenue side. This sign also depicts that Indian Scheduled Commercial Banks are not managing their assets properly. Increased NPAs lead to a deterioration in the asset quality of the banks, thus engulfing banks in the vicious circle of asset liability mismatch, resulting in input-output mismatch, and, hence, creating inefficiency 
among banks. Our findings are consistent with the earlier findings of Caner and Kontorovich (2004), Burki and Niazi (2006), Staub et al. (2010), Gulati (2011), Garza-García (2012), and Noor and Ahmad (2012).

\subsection{Total Investments to Total Assets (TITA)}

It is observed that total investments to total assets exhibits a positive relationship with the revenue efficiency scores. This positive relation depicts that Indian Scheduled Commercial Banks are required to maintain a specific proportion of their demand and time deposits in the form of gold and government approved securities. This safeguards their customer's money as well as provides funds to the government for the development of the economy. From these investments, banks get stable and consistent returns without risk. Investments help Indian Scheduled Commercial Banks to cushion themselves against bad loans and maintain high efficiency. Rather than losing their scarce resources in NPAs, it seems better for Indian Banks to invest in safer channels like government securities, which generate constant returns. Our results corroborate those of Ataullah and Le (2006) who reported that the low risk approach of banks helps them to earn steady returns, and, thus, maintain their efficiency. However, the results for $\mathrm{H}_{4}$ contradict Ketkar and Ketkar (2008) who reported a negative association of investments to total assets with efficiency. This study belongs to a time period immediately after reforms when banks were focusing more on earning high returns by lending loans and advances rather than investing in low return channels, thus leading to the contradictory results.

\subsection{Total Loans and advances to Total Deposits (TATD)}

Total Loans and advances to Total Deposits (TATD) reveal a positive relationship with Revenue Efficiency. This positive sign for $\mathrm{H}_{5}$ reflects that Indian Scheduled Commercial Banks are using their deposits in the most beneficial way. They are able to generate more revenues and profits from their loans and advances. Our results are in line with Niazi (2003), Burki and Niazi (2006), Ariff and Can (2008), and Raphael (2013) who also found a positive relation of loans and advances to deposit ratio with bank efficiency.

\subsection{Total Expenses to Total Income (TETI)}

Although Total Expenses to Total Income (TETI) was hypothesised to have a negative impact it turned out to be the reverse in the case of Revenue Efficiency suggesting that an increase in expenses leads to an 
increase in Revenue Efficiency. When banks adopt various strategies, such as offering high interest rates on deposits, it helps them to attract a large number of customers, thus resulting in a positive impact on the efficiency of the banks. Similarly, when cost is incurred on maintenance of the infrastructure, computers, software, etc., Revenue Efficiency becomes better. Molyneux and Thornton (1992) also observed a positive relationship of cost to income with the profitability of the banks for $\mathrm{H}_{6}$, suggesting that the high expenditure incurred by the banks helps them earn higher profits.

\subsection{Operating Expenses to Total Expenses}

As expected, Operating Expenses to Total Expenses (OETE) has a negative impact on Revenue Efficiency for $\mathrm{H}_{7}$, suggesting that, to a large extent, an increase in operating expenses decreases the efficiency of the banks. Our results are commensurate with Sufian (2009), Sufian and Habibullah (2010), Garza-García (2012), Sufian et al. (2012), Raphael (2013), and Sufian and Kamarudin (2015) who reported that operating expenses to total assets had a negative and significant impact on the efficiency.

\subsection{Business per Employee (BPE)}

Business per Employee (BPE) has a negative impact on the Revenue Efficiency, thus representing that an increase in BPE will lead to a decline in the Revenue Efficiency. This negative sign seems due to the fact that no doubt bank employees are generating more business, but, due to the loans turning into bad ones and becoming Non-performing Assets (NPAs), revenues are lost, and, hence, shows a depressing impact on bank efficiency. Also, Indian Scheduled Commercial Banks are not focusing on the customer perceived measures of quality, i.e., reliability, responsiveness, assurance, tangibles, and empathy, which negatively affect the Revenue Efficiency (Bhatia \& Mahendru, 2014). Our results are in coherence with studies like Kumar and Gulati (2009), and Gulati (2011) who found a negative relation of BPE with the efficiency of banks.

\subsection{Return on Assets (ROA)}

Return on Assets (ROA) reveals a negative relationship with revenue efficiency. Thus, depicting that if banks focus more on profits, it will lead to a reduction in revenue efficiency, which might be due to bank managers ignoring the concept of efficiency in their work, i.e., they only focus on individual terms so as to earn more and more profit and ignore 
the usage of inputs and the production of outputs. This negative sign depicts that bank managers focus on earning maximum profits, but ignore the efficiency of banks in totality. In order to compete with rivals, bank managers are given profitability targets. Hence, managers become pre-occupied in the accomplishment of the short-term profit-oriented targets, and the vision of achieving efficiency by balancing between inputs with the outputs is lost. Our results are supported by Chauhan and Pal (2009), Gulati (2011), and Raina and Sharma (2013) who found a negative association for ROA with Indian Banks' efficiency. Contrary to our results, Hassan (2005), Sufian and Noor (2009), Pančurová and Lyócsa (2013), Sanchez et al. (2013), and Raphael (2013) support a positive association with the efficiency of the banks. The contradiction is perhaps attributable to the differences in the sample size and countries.

\subsection{Spread to Total Assets (STA)}

Spread to Total Assets has a positive impact on the Revenue Efficiency suggesting that spread definitely affects the efficiency of banks positively. Spread is a primary source of bank revenue. It highlights the success of banks from their primary activities. It also represents that banks are managing their Asset-Liability match well. Our results are supported by Raphael (2013) who reported that Net Interest Income had a positive impact on the efficiency of banks.

\subsection{Non-Interest Income to Total Income to Total Assets (NIITI)}

It is observed that Non-Interest Income to Total Income exhibits a positive relationship with Revenue Efficiency. This positive relation describes that Indian Scheduled Commercial Banks are diversifying their activities to allied portfolios and non-interest income sources, and, thus, enhancing their efficiency scores. Whereas, Non-interest income is more stable and less risky compared to interest income, which varies due to the variation in the interest rates (Ariff \& Can, 2008). Our findings are in line with Sufian (2009), Gulati (2011b), and Raphael (2013) who found that Non-Interest Income had a positive effect on the efficiency of banks.

\subsection{Cash Deposit Ratio}

The Cash Deposit Ratio (CDR) reveals a positive relationship with Revenue Efficiency. The positive association with efficiency implies that an optimal amount of cash maintained with banks helps them to manage their business efficiently as they are able to fulfil the cash needs of depositors in a timely manner. 


\subsection{Liquid Assets to total Assets (LATA)}

Liquid Assets to total Assets (LATA) has a positive impact on Revenue Efficiency albeit insignificant. This positive sign depicts that liquid assets perhaps help banks to meet unexpected withdrawals, and, thus, help to sustain Revenue Efficiency. Our results are similar to Das and Ghosh (2009) who also found a positive and significant impact of liquid assets to total assets on efficiency.

\subsection{Size (LNTA)}

Size (LNTA) reveals a negative relationship with the revenue efficiency scores. The negative sign indicates that the larger banks tend to exhibit lower efficiency scores. Although larger banks are able to enjoy economies of scale by reducing their cost, extending their size beyond a certain point creates diseconomies (Eichengreen \& Gibson, 2001; Tariq \& Arfeen, 2012). Indian Banks are going in for excessive expansion for larger coverage, thus leading to decentralisation, which results in losing control with respect to administrative issues thereby leading to inefficiency. It becomes difficult for the management to keep a close eye on the activities of banks. Large banks have a problem with administration and management due to a large number of complex operations (Pasiouras \& Kosmidou, 2007). Our finding is consistent with previous studies, as Chauhan and Pal (2009), Sufian and Habibullah (2010), and San et al. (2011) also found a negative impact of size on the efficiency of banks.

\subsection{Time Dummy}

Time Dummy reveals a positive relationship with revenue efficiency. This depicts that Indian Scheduled Commercial Banks (SCBs) exhibited higher Revenue Efficiency Scores in the Reformatory Era compared to the Post Reformatory Era. This suggests that reforms improved the performance of banks. The reforms provided banks with a liberalised environment, which perhaps aided banks in adjusting their inputs and outputs in an optimum way. However, in the Post Reformatory Era, banks seemed to have disturbed the inputs and output equilibrium by investing instantly and exorbitantly in the upgrading of technology without a proportionate generation of returns, thereby leading to reduced efficiency during those years. In addition, the global financial crisis became a contributing factor in decelerating the performance of banks in the Post Reformatory Era. 


\subsection{Ownership Dummy}

The public Dummy reveals a positive relationship with efficiency. The positive coefficient of public dummy depicts that Public Sector Banks are better than Foreign Sector Banks throughout the study time period. Their long existence has been a major contributing factor in their performance compared to their counterparts. Private Dummy also portrays a positive relation with Revenue Efficiency. The positive coefficient of private dummy depicts that Private Sector Banks are better than Foreign Sector Banks throughout the study time period although the differences are significant at the 10 per cent level of significance. Thus, recommending that, to some extent, Private Sector Banks are earning better revenues due to their quality of service.

\subsection{Market Share in terms of Total Assets}

Market Share in terms of Total Assets has a positive impact on the Revenue Efficiency. The positive sign implies that banks with a larger market share are more efficient while those with a smaller proportion of the market lag behind in terms of the efficiency score.

\subsection{Inflation (INF)}

Inflation reveals a negative relationship for the revenue efficiency model. This highlights that inflation is unanticipated in the Indian Economy, and that Indian Scheduled Commercial Banks are slow in adjusting their interest rates as per inflation trends. This results in an increase in their costs more than their revenues, thus leading to a negative impact on the efficiency parameters. Our results are in line with Grigorian and Manole (2002), Jaffry et al. (2005), Brack and Jimborean (2010), Sufian et al. (2012), Pančurová and Lyócsa (2013), Sanchez et al. (2013), and Sufian and Kamarudin (2015) who also reported that inflation had a negative and significant impact on efficiency.

\subsection{Gross Domestic Product (LNGDP)}

The Log of Gross Domestic Product reveals a positive relationship with Revenue Efficiency. Consequently, the positive sign proposes that demand for financial services tends to grow more when the economy expands and the living standards of the people in the society increases. The favourable economic conditions prevailing in an economy helps banks to earn better returns from their loans and advances. Grigorian and Manole (2002), Jaffry et al. (2005), Sufian and Noor (2009), Sufian et 
al. (2012), and Sufian and Kamarudin (2015) support our results. The results of the above discussion are presented in a capsule form in Table 3.

Table. 3 Summary of the Expected and Actual signs of the explanatory variables

\begin{tabular}{|c|c|c|c|c|}
\hline \multicolumn{2}{|c|}{ Independent Variables } & \multirow{2}{*}{$\begin{array}{l}\text { Expected } \\
\text { Signs }\end{array}$} & \multirow{2}{*}{$\begin{array}{c}\text { Actual } \\
\text { Signs } \\
\text { Revenue } \\
\text { Efficiency }\end{array}$} & \multirow{2}{*}{ Reasons for Deviations } \\
\hline Framework & Symbol & & & \\
\hline \multirow[t]{2}{*}{$\begin{array}{l}\text { Capital } \\
\text { Adequacy }\end{array}$} & CAR & + & $-*$ & $\begin{array}{l}\text { Indian Scheduled Commercial Banks } \\
\text { have been facing a chronic problem of } \\
\text { NPAs. This forces them to maintain high } \\
\text { CAR going beyond the prescribed limit, } \\
\text { and make a safe product portfolio. This } \\
\text { generates a mismatch between the inputs } \\
\text { and outputs resulting in a negative } \\
\text { impact on the efficiency of the banks. }\end{array}$ \\
\hline & ETA & + & $+^{*}$ & -_--- \\
\hline \multirow{3}{*}{$\begin{array}{l}\text { Asset } \\
\text { Quality }\end{array}$} & NPANA & - & $-*$ & $\begin{array}{ll}----- \\
-9\end{array}$ \\
\hline & TITA & $+/-$ & $t^{*}$ & ----- \\
\hline & TATD & $+/-$ & + & ----- \\
\hline \multirow{3}{*}{$\begin{array}{l}\text { Management } \\
\text { Soundness }\end{array}$} & TETI & - & $+* *$ & $\begin{array}{l}\text { Indian Banks adopt various strategies, } \\
\text { such as offering high interest rates on } \\
\text { deposits to attract a large number of } \\
\text { customers. This perhaps leads to a } \\
\text { positive impact on the Revenue } \\
\text { Efficiency of banks. }\end{array}$ \\
\hline & OETE & - & $--^{*}$ & $\begin{array}{ll}---- \\
-4\end{array}$ \\
\hline & $\mathrm{BPE}$ & + & $-* *$ & $\begin{array}{l}\text { Indian Bank employees are generating } \\
\text { more business, but, due to the loans } \\
\text { turning into bad ones and becoming } \\
\text { Non-performing Assets (NPAs), } \\
\text { revenues are lost, hence, showing a } \\
\text { depressing impact on the Banks' Revenue } \\
\text { Efficiency. }\end{array}$ \\
\hline \multirow[t]{3}{*}{$\begin{array}{l}\text { Earning } \\
\text { Quality }\end{array}$} & $\mathrm{ROA}$ & + & $-* *$ & $\begin{array}{l}\text { Indian Bank managers focus on earning } \\
\text { maximum profits, and the vision of } \\
\text { matching inputs and outputs is lost. This } \\
\text { leads to a negative impact of ROA on the } \\
\text { efficiency of banks. }\end{array}$ \\
\hline & STA & + & $+* *$ & ----- \\
\hline & NIITI & + & $+* *$ & ----- \\
\hline \multirow{2}{*}{$\begin{array}{l}\text { Liquidity } \\
\text { Management }\end{array}$} & CDR & $+/-$ & $+^{*}$ & ------ \\
\hline & LATA & - & + & $\begin{array}{ll}----- \\
\end{array}$ \\
\hline \multirow{2}{*}{$\begin{array}{l}\text { Bank Size } \\
\text { Time }\end{array}$} & LNTA & $+/-$ & $-^{*}$ & ----- \\
\hline & $\mathrm{TD}$ & $+/-$ & $+* * *$ & $\begin{array}{ll}----- \\
\end{array}$ \\
\hline \multirow{3}{*}{$\begin{array}{l}\text { Industry } \\
\text { Specific }\end{array}$} & PUBD & $+/-$ & $+^{*}$ & ------ \\
\hline & PVTD & $+/-$ & $+* * *$ & $\begin{array}{ll}----- \\
\end{array}$ \\
\hline & MSTA & + & + & ----- \\
\hline \multirow{2}{*}{$\begin{array}{l}\text { Economy } \\
\text { Specific }\end{array}$} & INF & - & $-*$ & $\begin{array}{ll}----- \\
\end{array}$ \\
\hline & LNGDP & + & $+*$ & $\begin{array}{ll}----- \\
\end{array}$ \\
\hline
\end{tabular}




\section{Conclusion and Implications}

The results of factors affecting the Revenue Efficiency of Indian Scheduled Commercial Banks depicts that several bank, industry and economy specific variables affect the efficiency of Indian Scheduled Commercial Banks. Specifically, the CAMEL Framework highlights that it significantly influences the efficiency of banks. The results depict that CAR and NPAs have a negative and significant impact on the revenue efficiency of banks, thus indicating that banks should focus on credit risk management and Asset Liability Management. In order to improve the performance, Indian Banks Managers should focus more on credit risk management; they should follow strict credit appraisal policies and commence careful project monitoring departments to evaluate the projects while granting loans. The effective and regular follow up of loans and advances is required, i.e., each quarter, banks should check the embezzlement or diversion of their funds in order to prevent loans and advances converting into NPAs. Moreover, bank staff need to be trained in credit skills, e.g., about proper documentation, security margins, checking credit worthiness of the borrowers through proper monitoring and information collection processes, etc., so that they can prevent loan and advances turning into NPAs. As a result, this will assist banks to evaluate credit risk more effectively and avoid the problems associated with non-performing assets.

Furthermore, Indian Banks need to focus more on Asset Liability Management. One of the measures of liquidity, i.e., the cash deposit ratio, has a positive relation with efficiency, but, when all the liquid assets were considered, the relation turns to be negative. This somewhat depicts that, except cash, Indian Scheduled Commercial Banks are not managing their liquid assets properly, thus leading to a mismatch in the outputs and inputs. In order to maintain a proper balance in outputsinputs (assets-liabilities), Indian Bank managers should utilise their liquid assets in the best possible way. Asset driven strategies need to be framed for correcting the mismatch focusing on shortening the duration of the asset portfolio. Similarly, liability driven strategies should also be formed by basically concentrating on lengthening the maturity profiles of liabilities. Indian Bank managers are required to keep in mind the inputoutput prices according to the country's dynamic environment so that they can benefit from the favourable economic environment and protect themselves from the adverse effects.

Academicians and researchers should try and offer more insights into banking efficiency through future research. For future research scope, the work can further be extended by considering other efficiency 
parameters as dependent variables. Various risks faced by banks and offbalance sheet activities can also be taken into consideration. Another possible direction for future research is that one could also investigate the impact of crises along with bank, industry, and economy specific factors on the efficiency of Indian Banks.

\section{References}

Alexiou, C., \& Sofoklis, V. (2009). Determinants of bank profitability: Evidence from the Greek banking sector. Economic annals, 54(182), 93-118.

Alshatti, A. S. (2015). The Effect of the Liquidity Management on Profitability in the Jordanian Commercial Banks. International Journal of Business and Management, 10(1), 62-72.

Ariff, M., \& Can, L. (2008). Cost and profit efficiency of Chinese banks: A nonparametric analysis. China Economic Review, 19(2), 260-273.

Ataullah, A., \& Le, H. (2006). Economic reforms and bank efficiency in developing countries: The case of the Indian banking industry. Applied Financial Economics, 16(9), 653-663.

Athanasoglou, P. P., Delis, M. D., \& Staikouras, C. K. (2006). Determinants of bank profitability in the South Eastern European region. (MPRA Paper No. 10274). Retrieved from http://mpra.ub.uni-muenchen.de/

Athanasoglou, P., Brissimis, S., \& Delis, M. (2005). Bank-specific, industry-specific and macroeconomic determinants of bank profitability (Working Paper No. 25). Greece: Bank of Greece. Retrieved from http://www.bankofgreece.gr/

Avkiran, N. K. (2000). Rising productivity of Australian trading banks under deregulation 1986-1995. Journal of Economics and Finance, 24(2), 122-14.

Bandaranayake, S., \& Jayasinghe, P. (2014). Factors Influencing the Efficiency of Commercial Banks in Sri Lanka. Retrieved from http://ssrn.com/

Bell, F. W., \& Murphy, N. B. (1968). Costs in commercial banking: A quantitative analysis of bank behavior and its relation to bank regulation (No. 41). Boston: Federal Reserve Bank.

Benston, G. J. (1965). Branch banking and economies of scale. The Journal of Finance, 20(2), 312-331.

Berger, A. N., \& Humphrey, D. (1997). Efficiency of Financial Institutions: International survey and directions for future research. European Journal of Operational Research, 98(2), 175-212.

Berger, A. N., \& Mester, L. J. (1997). Inside the black box: What explains differences in the efficiencies of financial institutions? Journal of Banking and Finance, 21(7), 895-947.

Bhatia, A., \& Mahendru, M. (2014). A comparative study of labour productivity in public, private and foreign sector banks in India. Asia-Pacific Journal of Management Research and Innovation, 10(3), 239-251.

Bhatia, A., \& Mahendru, M. (2015), Revenue efficiency analysis of scheduled commercial banks in a dynamic environment. Indian Growth and Development Review, 8(2), 184-210. 
Bhattacharyya, A., Lovell, C. K., \& Sahay, P. (1997). The impact of liberalization on the productive efficiency of Indian commercial banks. European Journal of Operational Research, 98(2), 332-345.

Boyd, J. H., \& Runkle, D. E. (1993). Size and performance of banking firms: Testing the predictions of theory. Journal of Monetary Economics, 31(1), 47-67.

Brack, E., \& Jimborean, R. (2009). The cost-efficiency of French banks. (MPRA Paper No. 23471). Retrieved from https://mpra.ub.uni-muenchen.de/

Burki, A. A., \& Niazi, G. S. K. (2006). Impact of financial reforms on efficiency of state-owned, private and foreign banks in Pakistan (CMER Working Paper No. 06-49). Retrieved from http://saber.eaber.org/

Caner, S., \& Kontorovich, B. (2004). Efficiency of the banking sector in the Russian Federation with international comparison. ЭкономическийжурналВШЭ, 8(3), 357-375.

Cetorelli, N., \& Gambera, M. (2001). Banking market structure, financial dependence and growth: International evidence from industry data. The Journal of Finance, 56(2), 617-648.

Chauhan, P., \& Pal, V. (2009). Relative efficiency of Indian commercial banks. The Indian Journal of Commerce, 62(4), 1-17.

Chisti, K. A. (2012). The impact of asset quality on profitability of private banks in India. Journal of African Macroeconomic Review, 2(1), 126-146.

Das, A., \& Ghosh, S. (2009). Financial deregulation and profit efficiency: A nonparametric analysis of Indian banks. Journal of Economics and Business, 61(6), 509-528.

Dietrich, A., \& Wanzenried, G. (2009). What determines the profitability of commercial banks? New evidence from Switzerland. Paper presented at the 12th Conference of the Swiss Society for Financial Market Researches, Geneva. Retrieved from http:/ / citeseerx.ist.psu.edu/

Egesa, K. (2010). Financial Sector Liberalization and Productivity Change in Ugandas Commercial Banking Sector. The African Economic Research Consortium, Nairobi, Kenya. Retrieved from http://dspace.africaportal.org/

Eichengreen, B., \& Gibson, H. D. (2001). Greek banking at the dawn of the new millennium. Retrieved from http://ssrn.com/

Elsiefy, E. (2013). Determinants of profitability of commercial banks in Qatar: Comparative overview between domestic conventional and Islamic banks during the period 2006-2011. International Journal of Economics and Management Sciences, 2(11), 108-142.

Garza-García, J. G. (2012). Determinants of bank efficiency in Mexico: A twostage analysis. Applied Economics Letters, 19(17), 1679-1682.

Ghosh, S. (2009). Financial deregulation and profit efficiency: A non-parametric analysis of Indian banks. (MPRA Paper No. 24292). Retrieved from https://mpra.ub.uni-muenchen.de/

Grigorian, D., \& Manole, V. (2002). Determinants of commercial bank performance in transition: An application of data envelopment analysis (Working Paper 2850). Retrieved from http://ssrn.com/ 
Gulati, R. (2011). Efficiency in Indian commercial banks: A post-deregulation experience, (Doctoral Dissertation). Guru Nanak Dev University, Amritsar, India.

Gupta, O. K., Doshit, Y., \& Chinubhai, A. (2008). Dynamics of productive efficiency of Indian banks. International Journal of Operations Research, 5(2), 78-90.

Hassan, M. K. (2005). The Cost, profit and X-efficiency of Islamic banks. Paper presented at the 12th Annual Economic Research Forum Conference, Grand Hyatt, Cairo, Egypt.

Ioannis, A. G., Sophocles, B. N., \& Manthos, D. D. (2008). The efficiency of the Greek banking system and its determinants. Economic Bulletin, 30, 7-27.

Jaffry, S., Ghulam, Y., Pascoe, S., Cox, J., \& Anwar, S. (2005). Regulatory Changes and Productivity of the Banking Sector in the Indian Sub-continent [with Comments]. The Pakistan Development Review, 44(4), 1021-1047.

Joseph, A. L., \& Prakash, M. (2014). A study on analyzing the trend of NPA level in private sector banks and public sector banks. International Journal of Scientific and Research Publications, 4(7), 1-9.

Ketkar, K. W., \& Ketkar, S. L. (2008). Performance and profitability of Indian banks in the post liberalization period. Paper presented at The 2008 World Conference on National Accounts and Economic Performance Measures for Nations, Washington DC. Retrieved from http://indexmeasures.com/

Kosmidou, K. (2008). The determinants of banks' profits in Greece during the period of EU financial integration. Managerial Finance, 34(3), 146-159.

Kosmidou, K., Tanna, S., \& Pasiouras, F. (2005). Determinants of profitability of domestic UK commercial banks: Panel evidence from the period 1995-2002. Paper presented at the Money Macro and Finance (MMF) Research Group Conference, $45,1-27$.

Kumar, S. \& Gulati, R., 2008. An examination of technical, pure technical, and scale efficiencies in Indian public sector banks using data envelopment analysis. Eurasian Journal of Business and Economics, 1(2), pp.33-69.

Kumar, S., \& Gulati, R. (2009). Technical efficiency and its determinants in the Indian domestic banking industry: An application of DEA and tobit analysis. American Journal of Finance and Accounting, 1(3), 256-296.

Levin, R. (1997). Financial development and economic growth: Views and agenda. Journal of Economic Literature, 35(2), 688-726.

Makkar, A., and Singh, S. (2012). Evaluating the financial soundness of Indian commercial banks: An application of bankometer. Paper presented at the National Conference on Emerging Challenges for Sustainable Business conducted at IITRurkee, Haridwar, India.

McKevitt, D., \& Lawton, A. (1994). Public sector management: theory, critique and practice. London: Sage Publications Ltd.

Molyneux P. (1993). Structure and performance in European banking (Doctoral Dissertation). University of Wales, Bagnor, United Kingdom

Molyneux, P., \& Thornton, J. (1992). Determinants of European bank profitability: A note. Journal of banking \& Finance, 16(6), 1173-1178. 
Niazi, G. (2003). Measuringcost efficiency and productivity change of commercial banks in Pakistan, 1991-2000(Doctoral Dissertation). Quaid-I-Azam University, Islamabad, Pakistan.

Noor, M. A. N. M., \& Ahmad, N. H. B. (2012). The determinants of Islamic banks' efficiency changes: Empirical evidence from the World banking sectors. Global Business Review, 13(2), 179-200.

Pančurová, D., \& Lyócsa, S. (2013). Determinants of commercial banks' efficiency: Evidence from 11 CEE countries. Finance a Uver, 63(2), 152-179.

Pasiouras, F., \& Kosmidou, K. (2007). Factors influencing the profitability of domestic and foreign commercial banks in the European Union. Research in International Business and Finance, 21(2), 222-237.

Pasiouras, F., \& Kosmidou, K. (2007). Factors influencing the profitability of domestic and foreign commercial banks in the European Union. Research in International Business and Finance, 21(2), 222-237.

Pasiouras, F., Sifodaskalakis, E., \& Zopounidis, C. (2007). Estimating and analyzing the cost efficiency of Greek cooperative banks: An application of two-stage data envelopment analysis (Working paper). Retrieved from http://www.bath.ac.uk/

Perry, P. (1992). Do banks gain or lose from inflation? Journal of Retail Banking, 14(2), 25-31.

Portela, M. C. A. S., \&Thanassoulis, E. (2007). Comparative efficiency analysis of Portuguese bank branches. European Journal of Operational Research, 177(2), 1275-1288.

Purohit, K. K., \& Mazumdar, B. C. (2003). Post-martem of financial performance and prediction of future earning capability of a bank: An application of CAMEL rating and balanced scorecard. Indian Journal of Accounting, 34(1), 816.

Rajan, R. G., \& Zingales, L. (1995). What do we know about capital structure? Some evidence from international data, Journal of Finance, 50(5), 1421-1460.

Ram Mohan, T. \& Ray, S. C. (2004). Comparing performance of public and private sector banks: a revenue maximisation efficiency approach. Economic and Political Weekly, 1271-1276.

Raphael, G. (2013). Bank-specific, industry-specific and macroeconomic determinants of bank efficiency in Tanzania: A two stage analysis. European Journal of Business and Management, 5(2), 142-154.

Resende, M. (2000). Regulatory regimes and efficiency in US local telephony, Oxford Economic Papers, 52(3), 447-470.

San, O. T., Theng, L. L., \& Heng, T. B. (2011). A Comparison on Efficiency of Domestic and Foreign Banks in Malaysia: A DEA Approach. Business Management Dynamics, 1(4), 33-49.

Sanchez, B., Hassan, K. M., \& Bartkus, J. R. (2013). Efficiency determinants and dynamic efficiency changes in Latin American banking industries. Journal of CENTRUM Cathedra: The Business and Economics Research Journal, 6(1), 27-52.

Saxonhouse, G. R. (1976). Estimated parameters as dependent variables. American Economic Review, 66(1), 178-84. 
Semih Y. H., \& Philippatos, G. C. (2007). Efficiency of banks: Recent evidence from the transition economies of Europe, 1993-2000. European Journal of Finance, 13(2), 123-143.

Staikouras, C. K., \& Wood. G. E (2004). The determinants of European bank profitability. International Journal of Economics and Business Research 3(6), 5768.

Staub, R. B., Souza, G. D. S., \& Tabak, B. M. (2010). Evolution of bank efficiency in Brazil: A DEA approach. European Journal of Operational Research, 202(1), 204-213.

Sufian, F. (2009). Determinants of bank efficiency during unstable macroeconomic environment: Empirical evidence from Malaysia. Research in International Business and Finance, 23(1), 54-77.

Sufian, F., \& Kamarudin, F. (2015). Determinants of revenue efficiency of Islamic banks: Empirical evidence from the Southeast Asian countries. International Journal of Islamic and Middle Eastern Finance and Management, 8(1), 36-63.

Sufian, F., \& Noor, A. M. (2009). The determinants of Islamic banks' efficiency changes: Empirical evidence from the MENA and Asian banking sectors. International Journal of Islamic and Middle Eastern Finance and Management, 2(2), 120-138.

Sufian, F., \& Shah Habibullah, M. (2010). Developments in the efficiency of the Thailand banking sector: A DEA approach. International Journal of Development Issues, 9(3), 226-245.

Sufian, F., Kamarudin, F., Noor, M., \& Haziaton, N. H. (2012). Determinants of revenue efficiency in the Malaysian Islamic banking sector. Journal of King Abdulaziz University Islamic Economics, 25(2), 195-224.

Tariq, A. A., \& Arfeen, S. U. (2012). Is being big... better? A study of Norwegian saving banks (Doctoral Dissertation). University of Agder, Kristiansand and Grimstad, Norway.

Tobin, J. (1958). Estimation of relationships for limited dependent variables. Econometrica: Journal of the Econometric Society, 24-36. 